Journal of Development and Social Change, Vol. 3, No. 1, April 2020

p-ISSN 2614-5766, https://jurnal.uns.ac.id/jodasc

\title{
PERAN IBU DALAM PENYAMPAIAN PENDIDIKAN SEKSUAL PADA REMAJA PEREMPUAN DI KELURAHAN GANDEKAN, KECAMATAN JEBRES, KOTA SURAKARTA
}

\author{
Bima Eldo Yosafat ${ }^{1}$, Bagus Haryono ${ }^{2}$ \\ Program Studi Sosiologi Fakultas Ilmu Sosial dan Politik \\ Universitas Sebelas Maret Surakarta Indonesia \\ Email1: Bimaeldoyosafat@gmail.com,Email ${ }^{2}$ : bagusharyono@staff.uns.ac.id
}

\begin{abstract}
This research was conducted to describe the role of mothers in the delivery of teenage sex education in the Gandekan Village, Jebres District, Surakarta City. This type of research uses qualitative research methods with the case study method. Data collection uses participation collection, in-depth interviews, literature study, and documentation. The informants of this research are mothers who live in the Gandekan Village, Jebres District, Surakarta City. And having a teenage daughter. This study discusses the role that is carried out and which is carried out in the process of delivering the education section of their daughters. Using the AGIL theory (adaptation, goal achievement, integration, maintenance of latent patterns) put forward by Talcott Parsons, with four important basic elements that must be discussed in full and become a unity. The process is then processed. Data analysis techniques by collecting data, reducing data, presenting data and gathering conclusions.

The results of this study indicate that there is a difference between the role of mothers who play a role and the role of mothers who are involved in the delivery of sexy education to girls in the Village Gandekan, Jebres District, Surakarta City. The ability of adaptation (Adaptation) by the mother regarding the development of the pattern of child relationships in the midst of technological development can be agreed to be adequate, the goal of achieving damage to the child's future. The way mothers provide sex education (integration) to children is done through advice, messages and rules or restrictions given to children. The mother's ability to support patterns (Latency) through implanting values is hardly adequate. This is evident from the fact that there are still many children who refute the advice given by the mother.
\end{abstract}

Keywords: Surakarta, mother's role, sexual education, adolescents, AGIL theory.

Abstrak: Penelitian ini dilakukan bertujuan untuk menggambaran peran ibu dalam penyampaian pendidikan seksual pada remaja perempuan di Kelurahan Gandekan, Kecamatan Jebres, Kota Surakarta. Jenis Penelitian ini adalah menggunakan metode penelitian deskriptif kualitatif dengan metode studi kasus. Pengumpulan data menggunakan observasi partisipasi, wawancara mendalam, studi kepustakaan, dan dokumentasi. Informan Penelitian ini adalah Ibu-Ibu yang berdomisili di Kelurahan Gandekan, Kecamatan Jebres, Kota Surakarta. Serta memiliki anak remaja perempuan. Penelitian ini mengenai peran Ibu yang seharusnya dan yang senyataya terjadi dalam proses penyampaian pendidikan seksual 
terhadap anak remaja perempuan mereka. Menggunakan teori AGIL (adaptation, goal attainment, integration, laten pattern maintenance) yang dikemukakan oleh Talcott Parsons, dengan empat elemen dasar penting yang harus dipahami secara utuh dan menjadi sebuah kesatuan. Proses tersebut kemudian dianalisis. Teknik analisis data dengan pengumpulan data, reduksi data, penyajian data dan penarikan kesimpulan.

Hasil penelitian ini menunjukan bahwa ada perbedaan antara peran Ibu yang seharusnya dengan peran Ibu yang senyatanya terjadi kaitannya dengan penyampaian pendidikan seksual terhadap anak remaja perempuan di Kelurahan Gandekan, Kecamatan Jebres, Kota Surakarta. Kemampuan adaptasi (Adaptation) yang dilakukan ibu mengenai perkembangan pola pergaulan anak di tengah kemajuan teknologi dapat dikatakan cukup memadahi, pencapaian tujuan (Goal Attaintment) Ibu dalam memberikan pendidikan seks pada anak adalah untuk membentengi anak dari pengaruh pergaulan bebas, seks di luar nikah yang akan merusak masa depan anak. Cara ibu dalam memberikan pendidikan seks (Integration) pada anak dilakukan melalui nasihat, pesan dan aturan atau larangan-larangan yang diberikan pada anak. Kemampuan ibu dalam memelihara pola (Latency) melalui penanaman nilai-nilai mayoritas kurang memadahi. Hal tersebut terlihat dari masih banyak anak yang membantah nasihat yang diberikan ibu, tidak mengindahkan perkataan orangtua atau melanggar aturan yang diberikan pada anak.

Kata kunci: Surakarta, Peran Ibu, Pendidikan Seksual, Remaja, Teori AGIL.

\section{PENDAHULUAN}

Keluarga ialah suatu kumpulan manusia yang dihubungkan dan dipertemukan melalui pertalian/hubungan darah, perkawinan atau melalui adopsi (pengambilan) anak angkat. Di Barat (negara-negara industri Eropa dan Amerika Utara) yang masyarakatnya hidup dan bekerja di bidang industry maka keluarga didefinisikan sebagai satu satuan sosial terkecil yang mempunyai hubungan darah atau memiliki pertalian hubungan sah melalui perkawinan, pengambilan anak angkat dan sebagainya. Secara umum, keluarga inti yang kita kenal, memiliki komposisi unsur yang terdiri atas ayah, ibu, dan anak-anak. Hubungan-hubungan sosial keluarga berlangsung intim berdasarkan ikatan perasaan dan batin yang kuat, di mana orang tua berperan mengawasi serta memotivasi untuk mengembangkan tanggung jawab sosial dalam keluarga dan masyarakat. Sedangkan menurut Friedman (1998: 35) mendefinisikan bahwa, keluarga merupakan kumpulan dua orang atau lebih yang hidup bersama dengan keterikatan aturan atau emosional, dan di dalamnya setiap anggota mempunyai peran masing-masing yang merupakan bagian dari anggota keluarga tersebut.

Keluarga menjadi sangat penting serta menjadi prioritas utama dalam pembangunan berkelanjutan di negara Indonesia, hal ini terbukti dengan banyaknya program pemerintah pusat maupun daerah yang bertujuan untuk mengawasi serta menstimulasi setiap keluarga di Indonesia supaya berkembang dan dapat meningkatkan sumber daya manusia. Program pemerintah sudah tercanang sejak dulu hingga sekarang dan diharapkan terus berkelanjutan. Program pemerintah yang berfokus pada keluarga setiap periodenya selalu mengalami 
perkembangan dan perubahan karena dituntut untuk selalu berjalan seiring dengan perkembangan zaman yang berubah dengan sangat cepat dan dinamis.

Pendidikan seksual bagi remaja sangat penting. Menurut Ulwan (1996: 31) pendidikan seks adalah upaya pengajaran, penyadaran dan penerangan tentang masalahmasalah yang berkenaan dengan naluri seks dan perkawinan. Hal itu dimaksudkan agar jika anak telah tumbuh menjadi seorang pemuda dan dapat memahami unsur-unsur kehidupan, ia telah mengetahui masalah-masalah mana yang harus dilakukan dan tidak boleh dilakukan.

Pendidikan seks yang diberikan pada remaja antara lain bertujuan untuk mencegah perilaku atau perbuatan yang mengarah pada hal-hal yang melanggar moral, etika, dan juga agama. Hal ini dimungkinkan karena remaja merupakan masa dimana seseorang mengalami masa transisi karena adanya perubahan-perubahan tertentu. Perubahan tersebut juga berkaitan dengan perilaku seksual. Berkaitan dengan hal ini Sarwono mengungkapkan bahwa perubahan psikologis yang terjadi pada remaja meliputi intelektual, kehidupan emosi, dan kehidupan sosial. Perubahan fisik mencakup organ seksual yaitu alat-alat reproduksi sudah mencapai kematangan dan mulai berfungsi dengan baik (Sarwono, 2006: 71).

Terlepas dari penjelasan singkat mengenai keluarga serta, setiap keluarga diharapkan mampu memberikan pendidikan tambahan guna melengkapi ilmu pengetahuan, wawasan, maupun berbagai macam jenis ilmu lainnya yang sudah diajarkan di sekolah. Salah satu contoh pendidikan yang tidak diajarkan di sekolah adalah pendidikan mengenai norma, nilai, perilaku dan masih banyak lagi. Pendidikan yang diberikan oleh keluarga diharapkan mampu membentuk karakter dan perilaku setiap anak atau individu menjadi lebih baik supaya menjadi pribadi yang tidak hanya hebat dalam kecerdasan namun mampu menunjukkan pada khalayak ramai memiliki sikap dan perilaku yang tidak kalah hebat, disinilah peran keluarga terkusus peran ibu didalam pendidikan menjadi sangat penting.

Peranan ibu menjadi penting karena ibu adalah sebuah bagian dari keluarga inti, peranan ibu sangatlah luas dan menjangkau setiap sendi kehidupan keluarga. Tak terkecuali dalam perannya menyampaikan pendidikan sedari dini kepada setiap anaknya. Hal ini menunjukkan bahwa setiap ibu harus memiliki kapabilitas untuk menyampaikan wawasan atau pengetahuan kepada anaknya. Yang nantinya apabila wawasan atau pengetahuan tersebut telah disampaikan kepada anaknya, maka anaknya akan memiliki kemampuan untuk mengerti dan menjaga diri guna menghindari kejadian yang tidak diinginkan, kaitannya dengan penelitian ini adalah kekerasan seksual maupun penyimpangan seksual.

Berdasarkan ungkapan di atas, dapat dikatakan bahwa peran ibu sangat penting dalam memberikan pendidikan seks bagi remaja. Berkaitan dengan hal tersebut, Marijan mengungkapkan bahwa pendidikan seorang ibu terhadap anaknya merupakan pendidikan dasar yang tidak dapat di abaikan sama sekali. Maka dari itu, seorang ibu hendaklah yang bijaksana dan pandai mendidik anak-anaknya, sebagian orang mengatakan kaum ibu adalah pendidik bangsa (Marijan, 2012: 20).

Permasalahan yang akan diangkat oleh peneliti menggabungkan dua isu penting yaitu keluarga dan pendidikan atau lebih tepatnya pendidikan didalam keluarga yang akan mendalami tentang pendidikan seksual khususnya pada remaja. Isu ini menjadi perhatian peneliti karena melihat banyaknya kasus pelecehan maupun kekerasan seksual yang terjadi di 
Indonesia khususnya Provinsi Jawa Tengah. Solidaritas Perempuan untuk Kemanusaiaan, Hak Asasi Manusia Solo Raya (Spek HAM) mencatat kasus kekerasaan pada perempuan di Jawa Tengah hingga Oktober 2017 mencapai 1.303 kasus. Di mana 523 kasus merupakan kasus kekerasan seksual, sedangkan kasus kekerasan fisik mencapai 496 kasus. Dijelaskan oleh koordinator Spek HAM Solo Raya yaitu Fitri Haryani, dari kasus kekerasan tersebut usia korban yang mengalami kekerasan paling tinggi di rentang usia 13-18 tahun yakni 445 orang (http://nasional.republika.co.id, diakses Sabtu, 5 Mei 2018).

Dengan banyaknya jumlah kasus kekerasan dan pelecehan seksual yang menimpa kaum remaja menyebabkan peneliti ingin sekali mengetahui bagaimana sesungguhnya peran keluarga dalam pendidikan seksual pada remaja. Tidak bisa dipungkiri bahwa kasus pelecehan maupun kekerasan seksual sedang marak terjadi dimana saja, kapan saja, oleh siapa saja, dikarenakan pendidikan seksual diyakini haruslah ditempatkan pada barisan terdepan dalam pencegahan kasus pelecehan maupun kekerasan seksual yang dialami oleh remaja.

Kelurahan Gandekan dipilih oleh peneliti dikarenakan daerah tersebut memiliki jumlah penduduk yang masuk ke dalam kategori remaja berjumlah 1.338 jiwa, terbagi dalam 702 laki-laki dan 636 perempuan. Selain itu di Kelurahan Gandekan seringkali dijadikan rujukan dan tempat penelitian untuk beberapa mata kuliah yang telah diselesaikan oleh peneliti. Selain itu, di Kelurahan Gandekan. Diharapkan dalam penelitian ini mampu menjelaskan situasi serta kondisi real didalam masyarakat mengenai peran keluarga terkhusus ibu dalam penyampaian pendidikan seksual pada remaja perempuan yang akan didukung oleh data-data yang mendalam.

Pada akhirnya peneliti tertarik untuk meneliti bagaimana peran keluarga terkusus Ibu dalam menyampaikan pendidikan seksual pada remaja perempuan di Kelurahan Gandekan untuk itu penulis melakukan penelitian yang diberi judul Peran Ibu Dalam Penyampaian Pendidikan Seksual Pada Remaja Perempuan Di Kelurahan Gandekan, Kecamatan Jebres, Kota Surakarta. Diharap dapat merangkum dan sudah menjelaskan latar belakang di atas.

\section{METODE PENELITIAN}

Penelitian tentang peran Ibu dalam penyampaian pendidikan seksual pada remaja perempuan di Kelurahan Gandekan Kota Surakarta menggunakan metode penelitian deskriptif kualiatif dengan strategi studi kasus. Metode penelitian kualitatif (qualitative research) memiliki beberapa macam definisi dan Bogdan dan Taylor (Moleong, 2007: 4) mendefinisikan metodologi kualitatif sebagai prosedur penelitian yang menghasilkan data deskriptif berupa kata-kata tertulis atau lisan dari orang-orang dan perilaku yang dapat diamati. Pendekatan ini diarahkan pada latar dari individu tersebut secara holistik (utuh). Jadi dalam hal ini tidak boleh mengisolasikan individu atau organisasi ke dalam variabel atau hipotesis, tapi perlu memandangnya sebagai bagian dari suatu keutuhan. Menurut Nasution (2003: 5) penelitian kualitatif adalah mengamati orang dalam lingkungan, berinteraksi dengan mereka dan menafsirkan pendapat mereka tentang dunia sekitar, kemudian Nana Syaodih Sukmadinata (2005: 60) menyatakan bahwa penelitian kualitatif (qualitative research) adalah suatu penelitian yang ditujukan untuk mendiskripsikan dan menganalisis 
fenomena, peristiwa, aktifitas sosial, sikap, kepercayaan, persepsi, pemikiran orang secara individu maupun kelompok.

Dalam penelitian ini digunakan pendekatan studi kasus sebagai bagian dari penelitian kualitatif. Studi kasus berfokus pada spesifikasi kasus dalam suatu kejadian baik itu yang mencakup individu, kelompok budaya, ataupun suatu potret kehidupan. Selama tiga dekade, studi kasus telah didefinisikan oleh lebih dari 25 ahli. Creswell (2010: 20) mengatakan bahwa studi kasus merupakan strategi penelitian di mana di dalamnya peneliti menyelidiki secara cermat suatu program, peristiwa, aktivitas, proses, atau sekelompok individu. Yin (2011: 1) mengatakan studi kasus adalah sebuah penyelidikan empiris yang menginvestigasi fenomena kontemporer dalam konteks kehidupan nyata, khususnya ketika batas antara fenomena dan konteks tidak begitu jelas. Ary dalam Idrus (2009: 57), studi kasus adalah suatu penyelidikan intensif tentang seorang individu, namun studi kasus terkadang dapat juga dipergunakan untuk menyelidiki unit sosial yang kecil seperti keluarga, sekolah, kelompok-kelompok "geng" anak muda. Studi kasus dalam penelitian ini difokuskan pada beberapa ibu atau keluarga yang ada di wilayah Kelurahan Gandekan. Penelitian ini menelaah atau mengkaji mengenai peran ibu dalam penyampaian pendidikan seksual kepada remaja perempuan di Kelurahan Gandekan. Dengan demikian maka peneliti merasa bahwa metode penelitian deskriptif kualitatif dengan pendekatan studi kasus menjadi sangat tepat digunakan untuk menjelaskan secara mendalam tentang peran keluarga dalam penyampaian pendidikan seksual pada remaja.

\section{HASIL DAN PEMBAHASAN}

\section{Deskripsi Lokasi}

Kelurahan Gandekan adalah salah satu dari 51 kelurahan yang ada di Kota Surakarta, secara geografis berada di sebelah timur Kota Surakarta dengan luas wilayah $\pm 33 \mathrm{Ha}$, sebelah utara berbatasan dengan Kelurahan Purwodiningratan, Sebelah timur berbatasan dengan Kelurahan Sewu, sebelah selatan berbatasan langsung dengan Kali Pepe yang memisahkan wilayah Jebres dengan wilayah Kecamatan Pasarkliwon dan sebelah barat berbatasan dengan Kelurahan Sudiroprajan. Wilayah Kelurahan Gandekan terbagi dalam 9 (Sembilan) Rukun Warga (RW) dan 36 (tiga puluh enam) Rukun Tetangga (RT).

Nama Gandekan berasal dari kata "GANDEK" yang artinya abdi dalem Keraton yang tugasnya sebagai pesuruh khusu Raja. Gandek bertuga sebagai penghubung antara Raja dengan abdi dalem atau sentana dalem yang dibutuhkan untuk menghadap Raja. Dalam pasewakan (pertemuan), abdi dalem gandek bertugas membawa benda-benda upacara. Abdi dalam gandek biasanya terdiri dari abdi dalem putri (wanita). Kepalanya disebut Lurah, sebutannya "Nyai Lurah".

Gandekan, pada saat kekuasaan raja-raja di Surakarta adalah suatu perkampungan tempat tinggal seorang Gandek. Kampung Gandekan ada 2 (dua) yaitu Gandekan Tengan dan Gandekan Kiwo. Gandekan Tengen terletak di sebelah kanan pusat Keraton Surakarta, sedangkan Gandekan Kiwo letaknya di sebelan kiri Keraton Surakarta.

Mereka adalah di bawah reh parentah Pepatih Dalem/Patih Keraton. Untuk Gandekan Tengan di bawah reh parentah Kepatihan Wetan, sedangkan Gandekan Kiwo di bawah reh 
parentah Kepatihan Kulon. Hal tersebut berlangsung sampai Kemerdekaan Republik Indonesia diproklamirkan. Ketika memasuki jaman kemerdekaan, Gandekan kiwo masuk menjadi wilayah Kelurahan Jayengan Kecamatan Serengan, sedangkan kampung Gandekan Tengen menjadi wilayah Kelurahan Gandekan Kecamatan Jebres.

\section{Peran Ibu Yang Seharusnya Dilakukan Dalam Penyampaian Pendidikan Seksual Pada Remaja Perempuan di Kelurahan Gandekan, Kecamatan Jebres, Kota Surakarta}

Peranan adalah suatu tugas yang diemban seseorang yang akan dipertanggung jawabkan hasilnya dikemudian hari. Peranan merupakan aspek dinamis dari status (kedudukan). Apabila seseorang melaksanakan hak-hak dan kewajibannya sesuai dengan status yang dimilikinya, maka dapat dikatakan telah menjalankan peranannya. Maka peranan yang merupakan bentuk tingkah laku yang diharapkan dari orang yang memiliki kedudukan atau status. Antara kedudukan dan peranan tidak dapat dipisahkan. Tidak ada peranan tanpa kedudukan. Kedudukan tidak berfungsi tanpa peranan Menurut Komarrudin (1994: 34), yang dimaksud peranan adalah sebagai berikut:

a. Bagian dari tugas utama yang yang harus dilaksanakan seseorang

b. Pola yang diharapkan dapat menyertai suatu status

c. Bagian atau fungsi seseorang dalam kelompok prenata. Fungsi yang diharapkan dari seseorang atau menjadi karakteristik yang ada padanya.

d. Fungsi setiap variabel dalam hubungan sebab akibat

Pada kebanyakan keluarga, ibulah yang memegang peranan terpenting terhadap anakanaknya. Sejak anak itu di lahirkan, ibulah yang selalu di sampingnya. Ibulah yang memberi makan dan minum, memelihara, dan selalu bercampur gaul dengan anak-anak. Itulah sebabnya kebanyakan anak selalu cinta kepada ibunya daripada kepada anggota keluarga lainnya.

Pendidikan seorang ibu terhadap anaknya merupakan pendidikan dasar yang tidak dapat di abaikan sama sekali. Maka dari itu, seorang ibu hendaklah yang bijaksana dan pandai mendidik anak-anaknya, sebagian orang mengatakan kaum ibu adalah pendidik bangsa (Marijan, 2012: 20).

Sesuai dengan fungsi serta tanggung jawabnya sebagai anggota keluarga dapat disimpulkan bahwa peran ibu terhadap anak-anaknya adalah sebagai berikut:

a. Pemberi rasa kasih sayang,

b. Pengasuh, pendidik, dan pemelihara,

c. Tempat mencurahkan isi hati,

d. Pengatur kehidupan dalam rumah tangga,

e. Pembimbing hubungan pribadi,

f. Pendidik dalam segi emosional

Dari pengertian di atas dapat ditarik kesimpulan bahwa peranan adalah tugas yang diemban seseorang dalam menjalankan kewajiban dari tugasnya tersebut. Peranan erat kaitannya dengan hubungan sebab akibat, karena apabila tugas berjalan baik maka hasil yang akan didapatkan juga baik. Dari pengertian di atas dapat disimpulkan ibu adalah seorang 
perempuan yang telah mengandung, melahirkan, menyusui, membesarkan anak dengan cinta dan kasih sayang seutuhnya agar menjadi seorang yang berguna di berbagai bidang.

\section{Peran Ibu Yang Senyatanya Dilakukan Dalam Penyampaian Pendidikan Seksual Pada Remaja Perempuan di Kelurahan Gandekan, Kecamatan Jebres, Kota Surakarta}

Berdasarkan uraian mengenai peran ibu dalam penyampaian pendidikan seksual pada remaja perempuan di Kelurahan Gandekan, Kecamatan Jebres, Kota Surakarta yang sudah diuraikan di atas, dapat diambil pengertian bahwa orangtua khususnya ibu memiliki peran yang besar dalam memberikan pendidikan seksual kepada anaknya. Pendidikan seks pada anak juga merupakan hal yang penting dengan beberapa tujuan sebagai berikut: (a) Memberikan pemahaman dengan benar tentang materi pendidikan seks diantaranya memahami organ reproduksi, identifikasi dewasa/baligh, kesehatan seksual, penyimpangan seks, kehamilan, persalinan, nifas, bersuci dan perkawinan, (b) Menepis pandangan miring khalayak umum tentang pendidikan seks yang dianggap tabu, seronok, nonetis dan sebagainya, (c) Pemahaman terhadap materi pendidikan sek pada dasarnya memahami ajaran Agama, (d) Pemberian materi pendidikan seks disesuaikan dengan usia anak yang dapat menempatkan umpan dan papan, (e) Mampu mengantisipasi dampak buruk akibat penyimpangan seks, (f) Menjadi generasi yang sehat.

Penelitian ini menggunakan teori AGIL yang merupakan pengembangan teori fungsionalisme structural sebagaimana yang dipaparkan Talcott Person. AGIL merupakan empat syarat yang harus dicukupi oleh setiap masyarakat, kelompok atau organisasi dalam mencapai kebutuhan-kebutuhannya. Empat persyaratan yang dimaksud oleh Parsons dan digunakan pada penelitian ini, yaitu:

1. Adaptation (Adaptasi) yang nantinya akan membahas bagaimana ibu beradaptasi serta memahami situasi dan kondisi lingkungan sekitar anak remaja perempuan mereka.

2. Goal Attainment (Pencapaian Tujuan) yang membahas tujuan ibu menyampaikan pendidikan seksual pada anak remaja perempuan.

3. Integration (Integrasi) yang membahas bagaimana cara ibu memberikan pendidikan seksual pada anak remaja perempuan mereka.

4. Latent Patern Maintenance (Latensi) membahas mengenai kemampuan ibu dalam memelihara dan memperbaiki motivasi pola-pola individu dan kebudayaan.

Para ibu kebanyakan memahami pergaulan anak mereka di tengah perkembangan teknologi, seperti adanya HP, internet, media sosial dan lain sebagainya. Dampak negatif dari keadaan tersebut juga disadari oleh para ibu sehingga dapat dipahami apabila mereka mengkhawatirkan anak mereka. Kekhawatiran tersebut mendorong para ibu untuk lebih berhati-hati dan waspada terhadap perilaku anak mereka.

Pendidikan seks diberikan ibu pada anak melalui nasihat-nasihat, pesan tertentu, serta mendorong anak agar belajar dari apa yang pernah terjadi di lingkungan sekitar, misalnya ada anak tetangga yang hamil di luar nikah padahal masih sekolah. Selain itu ibu juga menerapkan aturan-aturan seperti agar tidak pulang terlambat, tidak pergi bersama teman lelaki dan harus meminta ijin terlebih dahulu apabila akan ke laur rumah, dan tidak menjalin hubungan dengan lawan jenis karena masih usia sekolah. 
Pendidikan seks yang diberikan pada anak diharapkan oleh para ibu agar anak mereka lebih berhati-hati dalam bergaul, menjaga diri agar tidak terjerumus ke pergaulan bebas, atau melakukan hubungan seks di luar nikah. Menurut Surtiretna, (2001: 23), pendidikan seks yaitu memberikan pengetahuan tentang perubahan biologis, psikologis dan psikososial sebagai akibat pertumbuhan dan perkembangan manusia atau sebuah pendidikan untuk memberikan pengetahuan tentang fungsi organ reproduksi dengan menanamkan moral, etika serta komitmen agama agar tidak terjadi "penyalahgunaan" organ reproduksi tersebut.

Menurut Ulwan (1996: 31) pendidikan seks adalah upaya pengajaran, penyadaran dan penerangan tentang masalah-masalah yang berkenaan dengan naluri seks dan perkawinan. Hal itu dimaksudkan agar jika anak telah tumbuh menjadi seorang pemuda dan dapat memahami unsur-unsur kehidupan, ia telah mengetahui masalah-masalah yang diharamkan dan dihalalkan. Lebih jauh lagi, ia bahkan mampu menerapkan tingkah laku Islami sebagai akhlak dan kebiasaan hidup, serta tidak diperbudak syahwat dan mempraktekkan cara-cara hedonisme.

Akan tetapi pendidikan seks yang diberikan dalam bentuk nasihat-nasihat, pesan atau pun aturan-aturan, tidak selalu sesuai dengan yang diharapkan. Beberapa anak tidak mengindahkan nasihat ibunya, terutama apabila dilarang untuk berpacaran. Sebagian yang lain mengatakan 'iya' di depan ibu tetapi melanggar apa yang dinasihatkan ibu. Namun ada juga yang anak yang tampak patuh dan tidak suka membantah apa yang dikatakan ibunya.

Kebanyakan ibu merasa kesulitan untuk memberikan pendidikan seks kepada anak secara baik dan lancar. Hal tersebut menunjukkan laternt patern maintenance atau kemampuan ibu dalam menanamkan nilai-nilai kepada anak masih dikatakan kurang memadahi. Hal itu dapat dibuktikan dengan banyaknya keluhan-keluhan ibu mengenai sikap dan perilaku anaknya yang suka membantah dan kurang mengindahkan kata-katanya. Ibu merasa bingung dan pusing dalam menghadapi sikap anak tersebut.

Kemarahan yang ditunjukkan pada ibu kepada anaknya dapat dikatakan sia-sia apabila kemarahan tersebut dilakukan setelah anaknya terlanjur melanggar aturan, yaitu melakukan hubungan seks di luar nikah. Dalam hal ini anak biasanya berani berterus terang karena sudah terlanjur hamil, padahal masih sekolah. Keadaan seperti itu tentu akan membuat orangtua, khususnya ibu, tidak saja menjadi marah tetapi juga kecewa terhadap anaknya. Dengan demikian dapat dipahami bahwa ibu tidak dapat menajaga dan mempertahankan aturanaturan yagn diciptakan untuk menghindarkan anak dari perilaku seksual di laur nikah.

\section{PENUTUP}

Berdasarkan hasil penelitian dan pembahasan yang sudah diuraikan di atas, maka dapat disimpulkan bahwa:

1. Kemampuan adaptasi yang dilakukan ibu mengenai perkembangan pola pergaulan anak di tengah kemajuan teknologi dapat dikatakan cukup memadahi, yaitu dapat dibuktikan melalui pengetahuan ibu tentang dampak buruk internet, media sosial yang dapat diakses bebas melalui HP. Selain itu ibu juga mengerti serta menyadari bahwa saat anak perempuan sudah mengalami menstruasi maka saat itu anak harus lebih 
berhati-hati karena masa tersebut menunjukkan anak sudah dewasa dan apabila melakukan hubungan seks akan mengakibatkan kehamilan.

2. Goal attainment atau pencapaian tujuan dalam memberikan pendidikan seks pada anak adalah untuk membentengi anak dari pengaruh pergaulan bebas, seks di luar nikah yang akan merusak masa depan anak, dan perilaku pacaran yang mengarah pada pelanggaran norma.

3. Integrasi atau cara ibu dalam memberikan pendidikan seks pada anak dilakukan melalui nasihat, pesan dan aturan atau larangan-larangan yang diberikan pada anak.

4. Kemampuan ibu dalam memelihara pola melalui penanaman nilai-nilai mayoritas kurang memadahi. Hal tersebut terlihat dari masih banyak anak yang membantah nasihat yang diberikan ibu, tidak mengindahkan perkataan orangtua atau melanggar aturan yang diberikan pada anak.

\section{DAFTAR PUSTAKA}

Bagus, Ida Wirawan. 2012. Teori - Teori Sosial Dalam Tiga Paradigma. Jakarta: Kencana. Bagong, Suyanto J. Dwi Narwoko. 2004. Sosiologi Teks Pengantar dan Terapan. Jakarta: Kencana Media Group

Desmita. 2010. Psikologi Perkembangan. Bandung: PT. Remaja Rosdakarya.

Friedman, M. Marilyn. 1998. Keperawatan Keluarga :Teori dan Praktik. Jakarta : EGC. https://www.kemsos.go.id, diakses pada Sabtu, 5 Mei 2018.

Idrus, M. 2009. Metode penelitian Ilmu Sosial. Yogyakarta: PT. Gelora Akasara Pratama. Komarudin. 1994. Ensiklopedia Manajemen. Jakarta: Bumi Aksara

Marijan. 2012. Metode Pendidikan Anak. Yogyakarta : Sabda Media.

Moleong, Lexy J. 2007. Metodologi Penelitian Kualitatif. Bandung : Remaja Rosdakarya

Nana Syaodih Sukmadinata. 2005. Metode Penelitian Pendidikan. Bandung: Remaja Rosda Karya.

Nasution. 2003. Metode Penelitian Naturalistik Kualitatif. Bandung: Tarsito.

Nina, Surtiretna. 2001. Bimbingan Seks bagi Remaja. Bandung: Remaja Rosda Karya.

Ulwan, Abdullah Nashih. 1996. Pendidikan Seks. Bandung: PT Remaja Rosdakarya.

Ritzer, G. 2012. Teori Sosiologi. Edisi Revisi. Yogyakarta: Pustaka Pelajar.

Saputra, Andrian. 2017. Korban Kekerasan Seksual di Jateng Kebanyakan Usia Produktif di http://nasional.republika.co.id, diakses pada Sabtu, 5 Mei 2018.

Sarwono, S.W. 2006. Psikologi Remaja. Jakarta: PT. Raja Grafindo Persada.

Yin, Robert K. 2011. Studi Kasus: Desain dan Metode. Jakarta: Rajagrafindo Persada. 